\title{
THE IMPACT OF THE LATE ROMAN ARMY IN PALAESTINA AND ARABIA*
}

\author{
ARIEL S. LewiN
}

The aim of the present paper is to investigate the relationship between the presence of the late Roman army in certain marginal areas of the Near East bordering the desert and the economic and demographic growth of those territories. Should we assume that the presence of the army was a prerequisite condition of their development? Or, on the contrary, must we assume that indigenous peoples in those regions were able to develop agriculture independently of Roman military presence? If so, we could be forced to admit that the introduction of the army into marginal lands was dictated by the imperial wish of exploiting those territories and that the soldiers started to undertake administrative duties in areas previously neglected by the imperial government.

The subject is an important one, but it is necessary to abandon preconceived ideas and to investigate specific situations using all available evidence. Scholars who are sceptical about the possibilities of indigenous cultures to develop an efficient agriculture underline that expansion and growth in such areas were a result of the imperial presence. A different approach invites us to take into account the capability of indigenous populations to expand the cultivation in the territories in which they were living using the most ingenious devices. Most probably, the answer to our question cannot be the same for every specific case we investigate.

In the second half of the first century the Roman army, by pacifying the desert tribe of the Garamantes, provided the necessary preconditions for the development of agrarian production in the Tripolitanian predesert area where a pastoral economy was quickly superseded by agricultural practice. The agricultural growth of the area was due to efforts made by the indigenous tribe of the Macae. Eventually, the predesert agrarian production became integrated into the imperial economy

\footnotetext{
* I thank Tali Erickson-Gini who helped me in the preparation of this paper. Basema Hamarneh and Zbigniew Fiema offered several suggestions.
} 
and olive oil produced in the wadis was exported in the Mediterranean. The army was not deployed in the predesert area until the end of the second century and consequently it did not directly influence the expansion of agriculture there. Moreover, there is no evidence of Roman colonization in the region. ${ }^{1}$ As has been stated:

The Roman contribution to the spread of agriculture was limited to enabling native elites in the towns and of the tribes to take advantage of their traditional position in society through the exploitation of land and labour. ${ }^{2}$

However, Roman expansion in southern Mauretania Caesariensis along the so called praetentura nova during the time of Septimius Severus appears to be a typical case of colonization and exploitation of a region initiated by imperial authorities. An important inscription has revealed that populi novi were transferred there from Africa Proconsularis, an overcrowded province at that time. The deployment of the Roman army along the frontier protected the growth of the new settlements and the process has been described as a 'colonisation agricole."3

In order to examine the impact that military units which were deployed in the marginal areas of Palestine and Arabia had on these territories I have selected two specific cases: a number of sites in the central and northern Negev and a handful of villages on the fringe of the desert in central Jordan. Recently published data enrich our knowledge of the economic and the social history of the areas under examination, and consequently we may try to understand the setting in which the army operated.

For the moment it is important to note that during the wide span of time between AD 300 and the Arab conquest there were changes in the way in which military units were deployed in the territory. Some units left their bases for other sites while others were newly introduced into the area. The patchy evidence suggests that the causes of changes in

\footnotetext{
${ }^{1}$ G. Barker - D. Gilbertson - B. Jones - D. Mattingly, eds., Farming the Desert, The Unesco Libyan Valleys Archaeological Survey. Vols. I-II (Paris/Tripoli/London 1996).

2 D.J. Mattingly, Tripolitania (Ann Arbor 1995), 147.

${ }^{3}$ N. Benseddik, 'Usinaza (Saneg): nouveau témoignage de l'activité de P. Aelius Peregrinus Rogatus sur la praetentura de Césarienne,' in A. Mastino, ed., Atti del IX convegno di studi sull'Africa Romana (Sassari 1992), 425-437; Ead., 'Septime Sévère, P. Aelius Peregrinus Rogatus et le limes de Maurétanie Césarienne,' in C. Lepelley and $\mathrm{X}$. Dupuis, eds., Frontières et limites géographiques de l'Afrique du nord antique. Hommage à Pierre Salama (Paris 1999), 89-107.
} 
the deployment of military units and so in the presence of the army must be found in varying imperial needs. Moreover, the economy of the sites under examination changed over time. The relations between specific indigenous economic activities and the presence of Roman armies must be evaluated on the basis of the existence of changing contexts.

The Negev, which had been part of the Roman province of Arabia since its conquest in Trajan's time, was transferred to the province of Palaestina during the time of Diocletian. However, during the fourth century, the provincial boundaries of Arabia and Palaestina underwent modifications several times and so the Negev and Southern Jordan belonged to one province after the other. At the time of Theodosius I the administrative boundaries took their definite shape, and the Negev and Southern Jordan were finally united to form a new provincial entity, Palaestina III or Salutaris. ${ }^{4}$

During the Nabataean and early Roman periods the Negev was crossed by the terminal section of the so-called Incense Road, leading to the important Mediterranean port of Gaza. Some caravan stations had been built by the Nabataean kings between Petra and Gaza with the aim of supporting trading activities. Oboda (Avdat) was one of the most important of these stations. Moreover, some other sites such as Sobota (Shivta) were occupied along minor lateral routes. Nessana overlooked the approach into the desert of Sinai. As far as we know such stations were inhabited by a tiny population and some agriculture started to develop in this marginal area where the annual rainfall very rarely exceeds $100 \mathrm{~mm} .{ }^{5}$

\footnotetext{
${ }^{4} \mathrm{Ph}$. Mayerson, 'P. Oxy. 3574: Eleutheropolis of the New Arabia', Zeitschrift fir Papyrologie und Epigraphik 53 (1983), 251-258 = Idem, Monks, Martyrs, Soldiers and Saracens (Jerusalem 1994), 204-211; idem, 'Palaestina vs. Arabia in the Byzantine Sources', Zeitschrift fir Papyrologie und Epigraphik 56 (1984), 223-230 = Idem 1994, op. cit., 224-231; Idem, 'Nea Arabia (P. Oxy. 3574): An Addendum to ZPE 53,' Zeitschrift fir Papyrologie und Epigraphik 64 (1986), 139-148 = idem 1994, op. cit., 256-258; 'Libanius and The Administration of Palestine', Zeitschrift fir Papyrologie und Epigraphik 69 (1987), 251-260 = Idem 1994, op. cit., 284-293; idem, 'Justinian's Novel 103 and the Reorganization of Palestine', Bulletin of the American Schools of Oriental Research 269 (1988), 65-71 = Idem 1994, op. cit., 294-300; J. Sipilä, 'Roman Arabia and the Provincial Reorganisations of the Fourth Century', Mediterraneo Antico 7 (2004), 317-348; idem, 'Fluctuating Provincial Borders in Mid-4th Century Arabia and Palestine', in A. Lewin et al., eds., The Late Roman Army in the Near East, (Oxford, forthcoming).

${ }^{5}$ See in general A. Lewin, 'Il Negev dall'età Nabatea all'epoca tardoantica', Mediterraneo Antico 5, 1 (2002), 319-375. For a description of the climatic zones of the Negev, see J. Shereshevski, Byzantine Urban Settlements in the Negev Desert (Beer Sheva
} 
Economic and military disruptions during the third century caused the cessation of traffic along the Petra-Gaza Road. Trade stations between Petra and Oboda were abandoned sometime about the reign of Severus Alexander. However, as far as Oboda itself is concerned, archaeological and epigraphic documentation reveals that this village, although it was affected by the crisis, was able to recover quickly. In particular, an inscription from Oboda shows that the inhabitants were renovating the temple area on the acropolis just after the mid-third century. ${ }^{6}$

The reign of Diocletian was one of intense activity at Oboda, as is indicated by inscriptions and archaeological findings. It is interesting to note that simultaneously some of the small stations along the route were reoccupied. Moreover, on the outskirts of Oboda itself a military structure was built, a fort for an auxiliary unit of approximately 500 men. The dimension of the fort is $100 \times 100$ meters and it had square and rectangular towers. ${ }^{7}$

This military presence was paralleled by intense activity in the Aravah Valley where a monumental inscription from the site of Yotvata recounts the building of a new military structure, a fort for an ala. The structure itself is relatively well preserved, measuring $19 \times 39 \mathrm{~m}$. It should be emphasized that during the same time the town of Aila on the Red Sea had become the legionary base of the legio $X$ Fretensis, previously stationed at Jerusalem. ${ }^{8}$

Diocletian dedicated himself to re-establishing the power of the Roman Empire. He intended to revitalize commercial routes and to provide the Roman Empire with military structures and soldiers along the periphery of the Near East and along the main inner roads. As

1991), 8-17.

6 T. Erickson-Gini, 'The Nabataean-Roman Negev in the Third Century cE', in Lewin et al., forthcoming, op.cit (n. 4). See also A. Negev, The Architecture of Oboda. Final Report (Jerusalem 1997).

7 T. Erickson-Gini, 'Nabataeans or Romans? Reconsidering the Date of the Camp at Avdat in the Light of Recent Excavations', in Ph. Freeman et al., eds., Limes XVIII. Proceedings of the XVIIIth International Congress of Roman Frontier Studies (Oxford 2002), 113-130.

${ }^{8}$ Z. Meshel, 'A Fort and Inscription from the Time of Diocletian at Yotvata,' Israel Exploration Fournal 39 (1989), 228-238; I. Roll, 'A Latin Imperial Inscription from the Time of Diocletian Found at Yotvata,' Israel Exploration fournal 39 (1989), 239-260; W. Eck, 'Alam Costia constituerunt: zum Verständnis einer Militärinschrift aus dem südlichen Negev', Klio 74 (1992), 395-400; U. Avner, G. Davies and J. Magness, 'The Roman Fort at Yotvata: Interim Report (2003),' Journal of Roman Archaeology 17 (2004), 405-412. 
part of this policy he transferred the legio $X$ to Aila in order to supervise commerce coming from the Red Sea and to tax it. ${ }^{9}$

However, the international commerce of the exotic goods passing through the Petra-Gaza road was never resumed on a large scale. But, as an important study has shown, Diocletian constructed a paved military road connecting Aila with the Negev. The new forts at Oboda and at Yotvata and some reoccupied minor stations between Oboda and the Aravah Valley were part of a system of military structures along this road. Milestones without inscriptions, found between Oboda and Shaar Ramon, must have been erected at that time along this new military road. ${ }^{10}$

Some surprising changes occurred in the Negev a few decades later. The fort at Oboda was abandoned approximately 20-30 years after its construction. Similarly, the smaller fort at Yotvata, heavily damaged by the earthquake of the year 363, was not rebuilt after that date. The absence of both these sites in the ducal list of Palaestina in the Notitia Dignitatum fits with the information drawn from the archaeological investigations. Moreover, so far scholars have not been able to find consistent proof that all the minor stations along the paved road in the Negev, where activity had been resumed at the time of Diocletian, continued to be occupied for a long time after the fourth century. ${ }^{11}$

Taking all data together we would be led to admit that such a reduction of military infrastructures represented a lack of interest by the imperial authority in investing in the region. We might think that emperors were no longer willing to invest in an area that did not react positively to the presence of the army sent to support it. However, other considerations reveal that a quite different trend was at work. In particular, literary sources inform us that at the time of Constantius II Elusa had already attained the status of a city: a new polis had emerged in the arid lands of the Negev. This city had a theatre and a local elite interested in cultural activities. ${ }^{12}$

9 A. Lewin, 'Diocletian: Politics and limites in the Near East,' in Freeman et al. 2002, op. cit. (n. 7), 91-101. On the Negev see now T. Erickson-Gini, 'The Nabataean-Roman Negev,' in Lewin et al., eds., op. cit. (n. 4), forthcoming.

${ }_{10}$ Ch. Ben David, 'The Paved Road from Petra to the 'Arabah-Commercial Nabataean or Military Roman?,' in Lewin et al., eds., op. cit. (n. 4), forthcoming.

${ }_{11}$ T. Erickson-Gini, 'The Nabataean-Roman Negev,' in Lewin et al., eds., op. cit. (n. 4), forthcoming.

${ }^{12}$ See Ph. Mayerson, 'The City of Elusa in the Literary Sources of the Fourth-Sixth 
Equally, by the time of Constantine Aila is attested as being a polis inhabited by wealthy councillors. Archaeological research conducted at the site of Aqaba where ancient Aila was located has revealed that from the time of Diocletian the city and its hinterland underwent their most intense development. The quantity and quality of the ceramic material found at Aqaba demonstrate how much the site benefited from the impact of the presence of the army and from the reopening of international commercial channels. ${ }^{13}$

The central Negev territory continued to thrive after the army had left Oboda. It is not completely clear when in the area around Oboda began the period of its most intense economic development and its demographic peak, but apparently a gradual process was already at work during the fourth century, reaching its peak in the fifth and in the sixth centuries. By this time the inhabitants of the North and Central Negev expanded agriculture to an unparalleled degree: farmsteads, villages and smaller settlements began to use hydraulic devices intensively in order to catch run-off water for the cultivation of vineyards and cereals. Wadi beds were used for cultivation and run-off water was also diverted to neighbouring terrain by way of barrages and dams. As a result the landscape underwent an important transformation: an area that had once been barren, where small road stations produced scant agricultural production, was now expanding its agricultural land to an unprecedented degree. In time sites that previously had been known as small road stations became wealthy villages adorned with churches. In Oboda also city walls were built. ${ }^{14}$

Let us return now to the subject of the present paper: the impact of the army. The Notitia Dignitatum reveals that around the year 400 no military unit had its base in the Central and Northern Negev

Centuries', Israel Exploration Fournal 33 (1983), 247-253 = Idem 1994, op. cit. (n. 4), 197-203.

13 S.T. Parker, 'The Roman 'Aqaba Project: The 1997-1998 Campaigns', Annual of the Department of Antiquities of Fordan 44 (2002), 373-394.

${ }^{14}$ See at least among the most recent publications H. Bruins, Desert Environment and Agriculture in the Central Negev and Kadesh-Barnea during Historical Times (Nijkerk 1986); R. Rubin, The Negev as a Settled Land (Jerusalem 1990), in Hebrew; J. Shereshevski, Byzantine Urban Settlements in the Negev Desert (Beer-Sheva 1991); G. Avni, Nomads, Farmers and Town Dwellers. Pastoralist-Sedentists Interaction in the Negev Highlands, Sixth-Eighth Centuries CE (Jerusalem 1996); Y. Hirschfeld, 'Farms and Villages in Byzantine Palestine,' Dumbarton Oaks Papers 51 (1997), 33-72; Negev 1997, op. cit. (n. 6). For the city walls at Oboda see Erickson-Gini 2002, op. cit. (n. 7), 119. 
south of Beersheva-Hatzeva. ${ }^{15}$ Oboda, Sobota, Elusa, and Nessana are not mentioned in this document. That villages and farmsteads in this area were not fortified supports the idea that no serious menace was foreseen. We should accept that the Bedouin tribes of the Sinai were not thought of as a very dangerous threat to the security of the settled population. Their activity did not very much exceed common banditry. Guardsmen under the command of irenarchs controlled and patrolled the main routes around the town. Such a police force at Elusa probably was fairly well capable of coping with this problem. Letters by Libanius inform us that there was serious competition in Elusa to obtain the position of irenarch, which points to the importance and popularity of the office. ${ }^{16}$

If we accept the idea that the villages of the Negev and the city of Elusa did not perceive the existence of any serious threat coming from the Bedouins of the Sinai we can be confident that the local municipal police was able to guarantee order. In addition, we could argue that some small detachments drawn from the units stationed at Birosaba, Birsama and Menois could have succoured activities of local police forces. ${ }^{17}$

After the evacuation of the fort of Oboda in the first decades of the fourth century the presence of soldiers in the Northern and Central Negev beyond the axis Birosaba-Hatzeva is attested only in the sixth century. However, we should observe that we cannot rely upon the information provided by the so called edict of Beer Sheva and by P. Ness. 39 . There is no proof that the latter's list of villages and cities subjected to taxation is a list of military bases. Besides a recent study of the socalled Edict of Beersheva, which comprises a recently published new fragment, has disproved the theory that all the names of the places

15 T. Erickson-Gini, 'The Nabataean-Roman Negev in the Third Century' in Lewin et al., eds, op. cit., (n. 4), forthcoming. For the date of the compilation of the pars orientis of the Notitia see C. Zuckerman, 'Comtes et ducs en Egypte autour de l'année 400 et la date de la Notitia Dignitatum Orientis', Antiquité tardive 6 (1998), 137-147.

${ }^{16}$ Libanius, Epistulae 100; 101; 532. Similarly a municipal chief of police is attested in a late antique inscription from Petra. See IGLS XXI 36 with the interpretation given by the editor, M. Sartre.

${ }_{17}$ Egyptian papyri reveals that already in the first centuries of the empire military units had been scattered in the province. See R. Alston, Soldier and Society in Roman Egypt. A Social History (London/New York 1995), 35-36. For late antiquity see $\mathcal{N D}$ or. XXXI; P. Pan. 2. On the equites Mauri scutarii stationed at Hermoupolis and Lycopolis, but mentioned as present also in the Oasis see O. Douch IV 457; P. Oasis 11. 
mentioned in the edict were bases for military units. In fact, only Zoara is clearly designated as a base of soldiers and also agrarienses of Elusa are mentioned, i.e. soldiers stationed in the hinterland of this town. ${ }^{18}$

Helpful and decisive information is provided by papyrus texts, inscriptions and archaeological findings. Some inscriptions found at Sobota (Shivta) show the active presence of military personnel in the village in the sixth century AD. In particular, an inscription dated to 599 mentions that a building was erected "epi tôn lamprotátôn priôrôn kai epi Fl. Iôannou Stephánou bikariou." Unfortunately the inscription is not in its original context and it is impossible to establish which kind of building is indicated. ${ }^{19}$ Moreover, other inscriptions show how the chiefs of the army stationed in Shivta were integrated in village life: they were involved in the building of churches and other Christian structures and buried their sons in the churches. ${ }^{20}$

Papyri from Nessana reveal as well that stratiotai, priores, a primicerius, an optio princeps, and doukikoi in the sixth century were living in the village, which is now called kastron Nessana. ${ }^{21}$ A characteristic element of Nessana is the presence of an enclosure in the upper city, the so called citadel which must be the military fort used by the soldiers mentioned in the papyri. The structure is of $35 \times 85 \mathrm{~m}$. and, according to archaeological evidence, may be dated to the fifth century or later. ${ }^{22}$ The Nessana papyri disclose the existence of a community where agriculture was practised with a certain degree of success. One document, dated to the 7 th century, shows that the inhabitants owned properties $12 \mathrm{~km}$. away from the site itself. Moreover, in other texts

${ }^{18}$ See L. Di Segni, 'The Beersheba Tax Edict Reconsidered in the Light of a Newly Discovered Fragment', Scripta Classica Israelica 23 (2004), 131-158. The same scholar rejects the idea that the edict must be dated in the first half of the fifth century and prefers a date in Justinian's reign.

${ }_{19}$ A. Negev, The Greek Inscriptions from the Negev (Jerusalem 1981), 65-66, n. 75. For the dating of the inscription to the year 599 see L. Di Segni, Dated Greek Inscriptions from Palestine from the Roman and Byzantine Period (Ph. D. Jerusalem 1997), 814-817.

${ }^{20}$ Negev 1981, op. cit. (n. 19), 52 n. 51; 55 n. 57; 60-61 n. 66; 65-66 n. 75; SEG XXXI 1429; 1435; 1444; 1453.

${ }^{21}$ P. Ness. 16-30.

${ }^{22}$ For a description of the structure see Shereshevski 1991, op. cit. (n. 5), 57-58, who argues that the fort was built after the North Church on the acropolis had been erected. The building was dated to the fifth century already by H. Colt, Excavations at Nessana I (London 1962), 31. On the contrary A. Negev, The Architecture of Mampsis. Vol. II. The Late Roman and Byzantine Periods (Jerusalem 1988), 2-3 unconvincingly argued that both the church and the fort were built in the first part of the fourth century. 
Nessana appears as a station from which some small caravans organized their travels into the desert. ${ }^{23}$

Another structure in the Negev resembles the one built at Nessana. It is the so called citadel of Oboda built on the acropolis, which is situated next to the religious section of the village. This structure of $61 \times 39$ meters should not be confused with the other fort that has been mentioned above, built in the Tetrarchic period and abandoned few decades later. Archaeologists argue that the citadel on the acropolis of Oboda can be dated to the fifth or sixth century. It is reasonable to assume that the structure was a military construction, although no military inscriptions have been found at Oboda. Both structures were surrounded by a wall that was 1,5-2 meters thick with massive square towers at the corners. The built up area of these forts was small, while the courtyard occupied most of the space. In the final stage there were twenty-seven small rooms in Nessana, and only two at Oboda. ${ }^{24}$

As far as Shivta is concerned the timing and reasons for the stationing of soldiers in the village may be further investigated. In the account written by Nilus, it appears that the young son of the writer, Theodolus, was kidnapped by a Bedouin tribe while touring the Sinai during a visit with local monks. The chief of the Arab group brought his prisoner into the village of Subaita, which must be identified with Sobota, in order to find buyers for the unfortunate young man. At first nobody seemed seriously interested in him and the Arab chief, irritated by the low sums of money offered for Theodolus, took him out of the gates of the town announcing that he would have him beheaded. Eventually Theodolus' fortunes changed and he was purchased by a Christian priest and taken to Elusa. ${ }^{25}$

23 P. Ness., passim.

24 Shereshevski 1991, op. cit. (n. 5), 45-47. It must be observed that at Avdat also a city wall was built, most probably in the fifth or sixth century. On the date of the erection of this structure see P. Fabian, 'Evidence of Earthquake Destruction in the Archaeological Record: The Case of Avdat,' in Big Cities World Conference on Natural Disaster Mitigation in Conjunction with the Tenth International Seminar on Earthquake Prognostic (Cairo 1996), 25. Negev 1988, op. cit. (n. 22), 2-3 again unconvincingly argued that the citadel of Oboda was built at the beginning of the fourth century. P. Ness. 39 mentions Oboda in a list of places subject to a fiscal contribution. However, it is impossible to prove that this is a list of military sites.

25 See Nilus Ancyranus, Narratio (ed. F. Conca). For the identification of Subaita with Shivta see Y. Tsafrir, L. Di Segni and Y. Green, Tabula Imperii Romani. Iudaea. Palaestina (Jerusalem 1994), 234. 
The facts that are given in this story must be dated at the end of the fourth or the beginning of the fifth century. It cannot be proved beyond any reasonable doubt whether the narratio describes real events or is historical fiction. However, Philip Mayerson has rightly pointed out that "at its worst, we may consider the narratio a kind of historical fiction in which the author has placed his major characters ... in a setting that is historically true." ${ }^{26}$ The story reveals that at that time Sobota was a site were Bedouins had contacts with the villagers. As we have stated above, there is no evidence indicating the presence of soldiers at this site before the sixth century. This seems to be confirmed by a passage in the narratio where the Arab who had kidnapped Theodolus threatens to behead him. Apparently nobody tries to intervene. This would have been unimaginable if any Roman soldiers were present in the village. Archaeological research establishes that in the fifth and sixth century Sobota and the surrounding area continued to develop. ${ }^{27}$ A similar trend can be detected at Nessana and Oboda. ${ }^{28}$ The overall increase of economic activities in this area must have attracted the attention of the imperial authorities who decided to dispatch soldiers to these villages.

We may assume that the soldiers stationed a Nessana, Sobota and Oboda contributed to making the main routes in the area safer. However, we should take it for certain that these forts were built simultaneously with the most intensive development of the Negev area. This historical consideration makes us doubt that the Bedouins of the Sinai had ever represented an obstacle to the tranquillity of these villages. ${ }^{29}$

${ }^{26} \mathrm{Ph}$. Mayerson, 'The Desert of Southern Palestine According to Byzantine Sources,' Transactions and Proceedings of the American Philological Association 95 (1964), 160-172, esp. $161=$ idem 1994, op. cit. (n. 4), 40-52, esp. 41. See also D. Caner, 'Sinai Pilgrimage and Ascetic Romance: Pseudo-Nilus' Narrationes in Context', in L. Ellis and F. Kidner, eds., Travel, Communication and Geography in Late Antiquity (Aldershot 2004), 135-147.

${ }^{27}$ Specifically on the development of Shivta see R. Erez Edelson, 'Settlement Distribution in the Byzantine Negev: A Case Study Comparing the Intra Settlement Area in the Negev Highlands and the Shivta Region', in A. Lewin and P. Pellegrini, eds., Settlements and Demography in the Near East, (Pisa-Roma 2006), 51-57. In general on the village of Shivta see A. Segal, The Byzantine City of Shivta (Esbeita), Negev Desert, Israel (Oxford 1983); Shereshevski 1991, op. cit., (n. 5), 61-81; Y. Hirschfeld, 'Social Aspects of the Late-Antique Village of Shivta', fournal of Roman Archaeology 16 (2003), 395-408.

${ }^{28}$ On Nessana see Shereshevski, 1991, op. cit. (n. 5), 49-60; D. Urman, Nessana Excavations and Studies (Beer Sheva 2005).

${ }^{29}$ This hypothesis has been ventured by M. Gichon in several publications. See among his most recent articles M. Gichon, '45 Years of Research on the Limes Palaestinae- 
On the contrary, a sedentarization of Bedouins may have contributed to the positive development of the region, as several studies claim. ${ }^{30}$

A question remains: Was the deployment of troops intended as part of a defensive system fit to cope with eventual attacks by Arab tribes living beyond the imperial boundaries? It is certain that a reorganization of the military apparatus in Palaestina III, which occurred during the reign of Anastasius, was prompted by an intensification of incursions of Arab tribes from outside the Roman frontiers. In all the sixth century such attacks continued led by the fearful confederation of the Lakhimds who supported the interest of the Persian empire. ${ }^{31}$ In whatever way this problem needs to be resolved, it is important to stress that when, in the late fifth or in the sixth century, the army was again deployed in the Negev the region had already begun its phase of large prosperity. In fact, scholars argue that the expansion of the wine production and the multiplication of the number of the sites occurred mostly since the beginning of the fifth century. ${ }^{32}$ As far as we can observe no military base was present in the Negev area in the fifth century and consequently, we are led to admit that the army was not a main factor behind such an economical development. The fact that the army was deployed at sites as Sobota and Oboda and also in the hinterland of Elusa shows that the imperial authority took up new responsibilities in a previously neglected region in which agriculture and commerce were expanding. ${ }^{33}$ In this region soldiers acted as a vital means of interaction between people and state due to their involvement in administrative and fiscal duties, and in policing the territory. ${ }^{34}$ It remains doubtful if the military presence was dictated by defensive needs against dangerous Arab tribes such as the ones who attacked Palestine at the time of Anastasius and, later, the Lakhmids. This cannot be excluded and the building of fortifications at Oboda and Nessana could support the idea.

\footnotetext{
The Findings and their Assessment in the Light of Criticism Raised (Clt-C4th), in Freeman et al. 2002, op. cit. (n. 7), 185-206.

${ }^{30}$ Avni 1996, op. cit. (n. 14).

31 A. Lewin, 'Amr ibn Adi, Mavia, the Phylarchs and the Late Roman Army: Peace and War in the Near East', in Lewin et al., forthcoming, op. cit. (n. 4).

${ }^{32}$ See n. 53.

${ }^{33}$ See already the important arguments by B. Isaac, 'The Army in the Late Roman East: The Persian Wars and the Defence of the Byzantine Provinces', in Av. Cameron, ed, The Byzantine and Early Islamic Near East. III. States, Resources and Armies (Princeton 1995), 140 = B. Isaac, The Near East under Roman Rule (Amsterdam 1998), 453-454.

${ }^{34}$ For a case, Egypt, where such a relation between soldiers and population is well attested see Alston 1995, op. cit. (n. 17), 81-101.
} 
The second case presented here is Umm al-Rasas. This site must be identified with Mefa, a phrourion mentioned in Eusebius' Onomasticon as located near the desert where a number of soldiers had been deployed. The Notitia Dignitatum attests that Mefa was the base of a unit of equites promoti indigenae and a structure found at the site has been identified as the unit's base. The fortress lies on top of a low hill and its dimensions are $158 \times 39$. According to archaeological research, it was built about AD 300. Some ceramic material from the site should be dated to the second part of the third century. Moreover, a fragmentary Latin inscription and a milestone point to the fact that some important activity at Mefa occurred at the time of the Tetrarchy. The fragmentary inscription, dated to the year 306, may recount the building of the fort while the milestone - now being published - has been dated to the Tetrarchic period. If we put all the documentation together it is hard to resist the conclusion that Diocletian and his colleagues were organizing a system of forts, connected by a peripheral route running East of the Via Nova Traiana along the desert, North and South of the Wadi Mujib. ${ }^{35}$

The study of ceramic material seems to show a gap in the occupation of the site in the fifth century. ${ }^{36}$ Consequently it should be argued that the equites promoti indigenae mentioned in the Notitia Dignitatum as the unit installed at Mefa had been transferred or disbanded some time after the compilation of the document. Mefa is mentioned in the Dialogue on the Vita Chrysostomi written by Palladius as a phrourion to which a bishop was exiled in the very first years of the fifth century. A small civilian settlement had arisen near the fort and the bishop was forced to live there. ${ }^{37}$ The site remained abandoned during the fifth century and apparently it was resettled as a civilian village in the sixth century when it grew to an astonishing magnitude. In the sixth century the entire area in the interior of the fort had become a village, filled with buildings, four of which were churches. In addition, the area outside the

35 A. Lewin, Kastron Mefaa, the equites promoti indigenae and the Creation of a Late Roman Frontier, Liber annuus 51 (2001), 393-304. For the system south of the Wadi Mujib see S.T. Parker, Romans and Saracens. A History of the Arabian Frontier (Winona Lake 1986); idem, ed., The Roman Frontier in Central Fordan. Interim Report on the Central Limes Arabicus Project 1980-1985 (Oxford 1987).

${ }^{36}$ E. Alliata, Ceramica romana, bizantina, araba, in M. Piccirillo and E. Alliata, eds., Umm al-Rasas Mayfa'ah. I. Gli scavi del complesso di S. Stefano (Jerusalem 1994), 279-282; B. Hamarneh, Topografia cristiana ed insediamenti rurali nel territorio dell'odierna Giordania nelle epoche bizantina ed islamica V-IX sec. (Città del Vaticano 2003), 49; 55-58; 247-248.

${ }^{37}$ P.L. Gatier, 'Romains et Saracènes: deux fortresses de l'Antiquité tardive dans des documents méconnus', Topoi 9 (1999), 218. 
fort developed into two other distinct sections containing a total of ten churches. Almost all churches were built in the second half of the sixth century and the greater part of the village was also built at this time. No traces of a military presence have emerged from the excavations or from the epigraphic documentation. Unless new evidence comes to light we might argue that the development of the village did not have anything to do with the presence of the army. However, in two mosaics found on the floor of two of the churches the village at that time was referred to as Kastron Mefaa. One of the mosaics is situated within the church of Lions built in the sixth century while the other is located in the church of S. Stephan built in the eighth century, in Ummayad times. Both show an image of the village itself, appearing as a walled town full of buildings and churches. Moreover, it had also external quarters and a kind of plaza with a column in the middle. ${ }^{38}$

The impetus behind the phenomenal growth of this marginal site can be easily discerned: an important discovery has revealed two inscriptions in a mosaic of a church in the village of Nitl in the vicinity of Umm alRasas. ${ }^{39}$ These two inscriptions mention the names of three Ghassanid phylarchs, one of whom was buried there. ${ }^{40}$ We may readily assume that Kastron Mefaa was also part of an area of central Jordan on the fringe of the desert area that was inhabited by the Ghassanids. The site was resettled during the sixth century due to the presence of this powerful confederation of tribes that was federate to the Romans in the marginal area of central Jordan. It is not known to what extent the Ghassanids were the new inhabitants of Kastron Mefaa and whether they were the people who built the many churches there. In addition, immigration into this marginal area by settled people who had been living in other parts of the province and may have benefited from the protection offered by the presence of the Ghassanids cannot be excluded as a factor.

It is significant to note that at Nitl a probably military structure has been observed. Apparently it should be dated to the 4th century.

${ }_{38}$ M. Piccirillo, 'La chiesa dei Leoni a Umm al-Rasas - Kastron Mefaa', Liber annuus 42 (1992), 195-225; M. Piccirillo and E. Alliata 1994, op. cit. (n. 35). See also P. Baumann, Spätantike Stifter im Heiligen Land (Wiesbaden 1999), 98-114; 142-182.

${ }_{39}$ On the site see Hamarneh 2003, op. cit. (n. 35), 125; 266-267.

${ }^{40}$ M. Piccirillo, 'The Church of Saint Sergius at Nitl. A Centre of Christian Arabs in the Steppe at the Gates of Madaba,' Liber annuus 51 (2001), 267-284; I. Shahid, 'The Sixth-Century Complex at Nitl, Jordan. The Ghassanid Dimension,' Liber annuus 51 (2001), 285-292. 
However, again no ceramic evidence dated to the fifth century has been found at this site. ${ }^{41}$ Clearly, Nitl underwent the same development as observed at Umm el Rasas: a military occupation in the fourth century with little civilian development of the site, a gap in the fifth century and resettlement and development into a relatively large village in the sixth century.

The fluctuations in the history of the occupation of the sites may be explained by the different political and military conditions which developed at different times in Late Antiquity. Diocletian stationed troops in some very marginal areas on the fringes of the desert that were not previously occupied. In time some units were withdrawn from the most marginal areas. This trend became quite significant in the fifth century. In this age the defense system in the marginal zones of central Jordan was probably dismantled. As has been argued above, there are no fifth century traces of occupation at Umm al-Rasas and Nitl, and the fort of Qasr el-Thuraiya - the last military installation built before the descent into the Wadi Mujib - was most probably abandoned in the fifth century. ${ }^{42}$ In a similar way the archaeological data seem to be compatible with an abandonment of Qasr Bshir and the military structures ancillary to El Lejjun. ${ }^{43}$ Coinage found at El Lejjun itself is interrupted between 451 and 491, and traces of reoccupation re-emerge after this date, but we cannot be sure about its character. According to Parker, after the earthquake of 502 only the courtyard of the fortress shows signs of occupation, but not the barracks. ${ }^{44}$

A recently published study argues that a more or less general abandonment of the military structures in the marginal areas of Central Jordan during the fifth century was dictated by Roman military strategy. Roman imperial government wished to relocate military manpower for other more urgent needs, which reveals its military priorities as well as its attitude to the urgency of problems arising along the frontiers of Palaestina and Arabia. Obviously it was taken for granted that such problems could be solved without the deployment of large military forces along the desert border there. The practice of redeploying military personnel away from the periphery of Palaestina and Arabia became more

${ }^{41}$ Hamarneh 2003, op. cit. (n. 35), 125; 266-267. I thank Basema Hamarneh for having informed me that also after the archaeological campaign of the summer 2005 no fifth century ceramic has emerged.

${ }^{42}$ Parker 1986, op. cit., (n. 34), 50.

${ }_{43}$ Parker 1986, op. cit., (n. 34), 53-55; 74-79.

${ }^{44}$ Parker 1986, op. cit., (n. 34), 58-74. 
visible during the time of Leo when Arab incursions seriously undermined the imperial image. The sheikh Amorkesos occupied the island of Jotabe, previously controlled by the Romans, and sacked the territory of Palaestina. Several years later on Arab tribes attacked the same province again. According to the sources, Anastasius is credited with having reinforced Roman military presence in Palaestina and the Near Eastern provinces after a period when the defenses had been neglected. ${ }^{45}$

Justinian considered the Ghassanid phylarchate a strong confederation capable to protect the empire from the Arab allies of the Persian Empire, the Lakhmids. ${ }^{46}$ The development of Umm al-Rasas and Nitl had something to do with the presence of the Ghassanids in the area. It is also possible that some soldiers were stationed again at Umm al-Rasas during the sixth century, which might explain why the site received the name of kastron, although no inscription or any other kind of evidence so far has revealed the presence of soldiers at the site, and there are no discernible military structures to be found that are similar to the ones at Nessana and Oboda. Similarly, the Petra papyri reveal that in the sixth century Sadaqa-Zadacatha and Admatha were called castra and that soldiers lived there. ${ }^{47}$ As far as Sobota is concerned soldiers were surely present there, but no fort has been detected in the site.

\section{Conclusions}

During Diocletian's times the Empire took a great effort to deploy military units in the periphery of the Near Eastern provinces. The new military infrastructures signalled the presence of imperial authority and its ability to guarantee the expansion of international and local commerce. During this period agriculture had the chance to develop in some not yet fully exploited areas.

45 See G. Fisher, 'A New Perspective on Rome's Desert Frontier', Bulletin of the American Schools of Oriental Research 336 (2004), 49-60. For the activity of Anastasius see A. Lewin, Amr ibn Adi, Mavia, in Lewin, et al., eds., op. cit. (n. 4), forthcoming.

${ }^{46}$ I. Shahid, Byzantium and the Arabs in the Sixth Century. Vol. I, parts 1-2 (Washington 1995); M. Whittow, 'Rome and the Jafnids: Writing the History of a 6th-c. Tribal Dinasty', in J.H. Humphrey, ed., The Roman and Byzantine Near East. Vol. 2 (Portsmouth 1999), 207-224.

47 Full documentation in Z.T. Fiema, 'The Military Presence in the Countryside of Petra in the 6th Century', in Freeman et al. 2002, op. cit. (n. 7), 133-134; Idem, 'The Byzantine Military in the Petra Papyri-A Summary', in Lewin et al., eds., op. cit. (n. 4), forthcoming. 
In Late Antiquity the Negev reached its economic and demographic peak. Bedouins intensified the process of sedentarization in the area. Military forces were withdrawn from Oboda at a quite early stage, and we are not informed about the presence of any army units in other sites in the Negev South of the axis Birosaba-Hatzeva until the sixth century. At that time the presence of the army is attested at Nessana, Sobota, Oboda, and in the countryside of Elusa. Moreover, the building of a citadel at Oboda seems to reveal the presence of the army there.

If so, we could appreciate how different the second presence of the army at Oboda must have been in respect to the earlier one. While in the beginning of the fourth century the soldiers had been deployed in a fortress outside the village, now a different solution was chosen. The old fortress was not reoccupied and the army became more integrated in the village society. The citadel was a military structure and it was used by the army, but most probably the soldiers lived in the village itself. The same goes for Nessana, where a citadel was built on the acropolis while no military structure is visible in Sobota. The consequences of military presence were different. It is logical to argue that in the fourth century the army had been introduced into the Negev as part of Diocletian's policy of supporting the commercial position of Aila.

Some scholars think that in the Negev the soldiers contributed directly to the economic development of the area. ${ }^{48}$ However, it is a matter of doubt whether the few hundreds of soldiers who were based at Oboda and scattered over minor stations along the paved road were capable of significantly enriching the area just by their presence.

Agricultural developments in the Negev area may not so much have been the result of state intervention, but owed more to organic, internal growth. ${ }^{49}$ Similarly, the traditionally held view that Palestine and the Negev in particular developed thanks to the influx of pilgrims, the

\footnotetext{
${ }^{48}$ Negev 1997, op. cit. (n. 6), 6.

${ }^{49}$ State intervention: R. Rubin, 'Urbanization, Settlement and Agriculture in the Negev Desert. The Impact of the Roman-Byzantine Empire on the Frontier,' Zeitschrift des deutschen Palästina-Vereins 112 (1996), 49-60; idem, 'Soldiers and Administrators: Society and Institutions in the Byzantine Negev', Mediterranean Historical Review 12 (1997), 56-73; M. Haiman, 'Agriculture and Nomad-State Relations in the Negev Desert in the Byzantine and Early Islamic Periods', Bulletin of the American Schools of Oriental Research 97 (1995), 29-53, criticized by B. Isaac, The Near East under Roman Rule [Amsterdam 1998], 152-153, who - following Shereshevski 1991, op. cit. [n. 5], 217-222 argues in favour of an organic growth of the Negev.
} 
activity of monks and external investment supported by the Christian Empire does not appear to be right. ${ }^{50}$ Such contributions were not completely insignificant, but there is a more specific factor that may explain economic growth in the area.

Recently studies by Doron Bar about human mobility in Late Roman Palestine have started to attract scholarly attention. Archaeological research revealed that some areas were abandoned while others were settled for the first time with particular intensity. The latter development is attributed by Bar to contemporary imperial legislation about fiscal exemptions and favourable terms of payment to people who would like to cultivate agri deserti. ${ }^{11}$ Although we do not have any specific information about these laws as to the Negev it is not impossible that peasants and landowners and even Bedouins living in the area took advantage of the opportunity offered by the law. But again, this does not mean that the imperial government organized the transfer of people from other areas to the Negev. In Late Antiquity the Negev maintained its specific Nabataean cultural identity, which indicates that its development was not due to the contribution of an external population. ${ }^{52}$

The economic factors causing the prosperity of the central Negev must be found in the production of wine, which started in the fourth century. By that time the territory had become involved in a large scale production of this product, which was brought to the port of Gaza, from where it could be exported. Consequently the marginal Negev area became integrated into the Mediterranean commercial network. Scholars have convincingly argued that "the data available indicate that the large-scale export of Palestinian wine commenced between circa $\mathrm{AD} 400$ and $450,{ }^{53}$ and it seems logical to assume that it was during

\footnotetext{
${ }^{50}$ Among the supporters of this theory see the differently articulated opinions expressed by M. Avi Yonah, 'The Economics of Byzantine Palestine,' Israel Exploration Fournal 8 (1958), 39-51; Ph. Mayerson, 'Urbanization in Palaestina Tertia: Pilgrims and Paradoxes,' Cathedra 45 (1987) = idem 1994, op. cit. (n. 4), 19-40. For criticism see Lewin 2002, op. cit. (n. 5).

${ }^{51}$ D. Bar, 'Frontier and Periphery in Late Antique Palestine,' Greek Roman and Byzantine Studies 44 (2004), 69-92; idem, 'Roman Legislation as Reflected in the Settlement History of Late Antique Palestine', Scripta Classica Israelica 24 (2005), 195-206.

52 See Lewin 2002, op. cit. (n. 5), 343-373. However, when in 293/294 at Oboda an elegant tower near the acropolis was built, the works were organized by a master carpenter coming from Petra. See Negev 1981, op. cit. (n. 19), 26-27, with n. 13. We must assume the existence of contact and relations between the central Negev and Petra.

${ }^{53}$ See the innovative views by S. Kingsley, 'The Economic Impact of the Palestinian Wine Trade in Late Antiquity', in S. Kingsley and M. Decker, eds., Economy and Exchange
} 
this period that an intensification of the production of wine took place in the central Negev.

The withdrawal of the military unit at Oboda did not cause difficulties to the village's economic and demographic growth. When Roman army units returned to the Negev in the late fifth or sixth century it settled in a prosperous area that had already entered the phase of its most intense development.

The military garrison at the fort of Mefa, which had been part of a chain of military posts to the East of the Via Nova Traiana, built by Diocletian, was withdrawn during the fifth century. In the following century, it became settled again and developed into a large village. It is not certain that a new garrison was again deployed at Mefa in the sixth century. It is equally doubtful whether the village took the name kastron because it was known that the village had taken the place of a previous fortress. But if we assume, as we may reasonably do, that Roman soldiers were not stationed at Mefa, it is possible to argue that they were not the key factor behind the development of the site and of the nearby village of Nitl. The new political situation on the border of the Empire dictated a new development: the Ghassanids were now contributing to the protection of the Eastern provinces and eventually to the population of some of the villages at the limits of agricultural lands. ${ }^{54}$

in the East Mediterranean during Late Antiquity (Oxford 2001), 44-68; idem, A Sixth-Century AD Shipwreck off the Carmel Coast, Israel. Dor D and Holy Land Wine Trade (Oxford 2002), $60-84$. One should note that the dimensions of the vats and wine installations in the Negev show that wine production was not limited to local consumption. But see also P. Fabian and Y. Goren, 'A New Type of Late Roman Storage Jar from the Negev', in J.H. Humphrey, ed., The Roman and Byzantine Near East, Vol. 3 (Portsmouth 2002), 145-153.

54 The idea that the Ghassanids were not nomads is vigorously argued by I. Shahid, Byzantium and the Arabs in the Sixth Century. Vol. 2. Part I (Washington 2002), 1-20. 